\title{
Service Involvement and Civic Attitudes of University Alumni: Later Correlates of Required Public Service Participation during College
}

\author{
Barbara E. Moely \\ Tulane University
}

\author{
Vincent Ilustre \\ Tulane University
}

\begin{abstract}
How is required public service during college related to later civic behavior? This article reports findings from a survey of 359 alumni, conducted two years after they completed their undergraduate studies at Tulane University. The alumni held positive views of the substantial public service requirement they had completed before graduating and saw it as influencing their later civic attitudes and career development. Public service activities in which they engaged post-graduation involved community service (volunteering, program development) and donations to local and national agencies; they reported little political or formal civic participation. Both co-curricular service and service-learning/public service academic course work during college predicted alumni service activities and civic attitudes. Especially, participation in more advanced and individualized public service academic experiences (public service internships, community-based research, and other advanced service-learning course work) was related to later civic outcomes.
\end{abstract}

Tulane University implemented a public service graduation requirement in 2006 as a way of increasing the involvement of the university in the rebuilding of New Orleans, which had been devastated by Hurricane Katrina the previous year. "Public service" at the university was defined as ". . . an informed, consensual, and mutually interactive engagement with people, institutions, and the environment, for the purpose of the progressive achievement of civic virtue and the promotion of the public good" (http://www2.tulane.edu/cps/ students/images/public-service-schmatic-large_1. jpg).

All undergraduates from 2006 onward have been required to complete the public service graduation requirement, which involves their completing at least two service-learning or community engagement courses. The Center for Public Service (CPS), established in 2006 and charged with implementing the requirement, has provided training, logistical support, and consultation to faculty and community agencies in an effort to create high-quality community engagement opportunities for students. New ways of involving students in leadership programs and research activities have been created, with increases over the years in the number and variety of academic service opportunities available. In 200607, the University offered 107 service-learning or advanced community-based courses to serve the students in the first class affected by the requirement as well as the more advanced students who could elect community-based courses. In the 201617 academic year, with all enrolled students needing public service courses to meet the requirement, the University offered 282 courses that students could use to satisfy the requirement (for an undergraduate student body of 6,662). In addition, students could complete other advanced courses that included a community-based public service component, such as internships or community-based research (CBR).

There was little precedent in 2006 for such a broad and sudden change in academic requirements, but after the tragic impact of the hurricane, bold steps were required (Ilustre, Lopez, \& Moely, 2012). Because the literature on student views of a service-learning requirement was limited and because some studies had reported negative effects of required service (Jones, Segar, \& Gasiorski, 2008; Marks \& Jones, 2004), we decided to begin a research project to learn about how students were reacting to the requirement. We surveyed entering students in 2006, 2007, and 2008, and then followed them at two- and four-year intervals through their time in college. We have reported elsewhere (Moely \& Ilustre, 2011, 2013, 2016a) that students felt positively about the requirement and continued to hold positive views as they progressed through college. They showed growth over time in civic attitudes, knowledge, and skills. The present study was conducted two years after the individuals in these cohorts had completed their undergraduate 
studies. We wanted to find out if alumni maintained the positive effects of their service during college as they moved on to the next phase of their lives.

There have been a number of studies on alumni attitudes and behaviors related to participation in service-learning or co-curricular service. Astin, Sax, and Avalos (1999) found that volunteer service during the college years had impacts on a large sample of alumni four years after graduation. Service participation during college was positively related to the number of hours alumni spent volunteering, their donations to colleges, and their civic values (valuing participation in civic action, environmental cleanup, and racial understanding). This study did not look at the impacts of academically based service, something that has been investigated in a number of more recent studies. Denson, Vogelgesang, and Saenz (2005), in a survey of graduates of 229 institutions, reported that service-learning produced gains in political engagement that were maintained up to six years after college. Political engagement included behaviors in support of political candidates (giving money, working with a political group, canvassing for a candidate, taking part in demonstrations or rallies, etc.). Generic volunteerism during college (community service other than service-learning) tended to have a positive effect as well, but it was not as strong as the impact produced by service-learning course experiences.

Fenzel and Peyrot (2005) conducted a telephone survey of 481 graduates of a religious-affiliated liberal arts college, three to nine years after they had completed their undergraduate studies. Both nonacademic community service and service-learning experiences during college were related to alumni involvement in community service and servicerelated careers, with the stronger effect produced by service-learning, especially if the courses were well designed and implemented.

Wilder, Berle, Knauft, and Brackmann (2013) found that alumni who had taken a service-learning course were more likely than other alumni of the same university to continue with civic and community engagement activities (community service and leadership, donating, etc.) after graduation. Caulfield and Woods (2013) asked alumni who had completed applied social science elective classes about the impact of these courses. The participants indicated that they had gained knowledge about social issues, and nearly all reported having engaged in socially responsible actions specific to that issue after course completion.

Looking at attitudes rather than civic behaviors, Hahn (2015a, 2015b), in a survey of Indiana University-Purdue University Indianapolis (IUPUI) alumni, found that both co-curricular service and the number of service-learning courses during college predicted alumni scores on the CivicMinded Professional scale. Hatcher has defined the civic-minded professional as one who is ". . . skillfully trained through formal education, with the ethical disposition as a social trustee of knowledge, and having the capacity to work with others in a democratic way to achieve public goods" (Hahn, 2015a).

Several studies have shown that participation in service-learning during college is seen by alumni as beneficial to career and personal development. Korfmacher (1999) asked the alumni of an Environmental Studies program about the later impacts of their experiences in a service-learning seminar in which students focused on a local environmental problem. The participants described skills they had acquired that were useful in their careers, such as learning to structure a problem-solving process, interviewing, working in groups, as well as technical skills. Newman and Hernandez (2011) mailed a survey to alumni who had participated in a servicelearning course (the "Minding Our Business" [MOB] program) up to 10 years earlier. In the MOB program, the college students had mentored middle school students in an entrepreneurship curriculum. Nearly all of the alumni who completed the survey felt positively about the program, recalling rewarding experiences during their participation. Although these alumni were not engaged in a great deal of service at the time of the survey (reporting only an average of 5.5 hours per year), nearly all (98\%) planned to engage in community service in the future. Most participants indicated that the experience had had a favorable impact on their career plans and on the development of their communication, teamwork, and leadership skills. Matthews, Dorfman, and $\mathrm{Wu}$ (2015) showed that alumni who had participated in service-learning were likely to earn higher salaries than similar graduates who had not done service-learning, although they did not differ in some other aspects of their employment.

Nearly all of the research to date has been conducted with populations in which students choose whether or not to be involved in service-learning or voluntary service, rather than participating to satisfy a requirement. One of the few studies concerned with required service during college was done by Keen and Hall (2008), who surveyed Bonner scholarship alumni. These are a select group of college students chosen for the Bonner program on the basis of their commitment to social justice and community engagement and their need for financial support to attend college. As part of the program, they are heavily involved in community service throughout their years in college. Keen and 
Hall found that all of the 41 program graduates who completed their survey were engaged in community service six years after graduation, compared with approximately two thirds of individuals in the comparison groups.

The Tulane University alumni in the present study completed a two-part public service requirement to graduate. The first part of the requirement involved the completion of a service-learning course during the first two years of college. To fulfill the second tier of the graduation requirement, students could choose either a second, more advanced, servicelearning course, or one of several other options. The most popular of these other options are public service internships and CBR.

Public service internships have been offered through the CPS since it began as a way to give students opportunities to build their skills through intensive community-based work so that they can gain experience in their fields of study while benefiting the community. Currently, 34 academic units (departments, schools, or programs) offer such internships, which involve 60 to 70 hours of unpaid service over a semester, along with weekly seminar meetings that deal with issues arising from community-based work in the academic discipline. Students must apply for entry into the internship program; they are eligible after completing their first year of college with a 3.0 grade point average (GPA) and satisfying the first part of the public service graduation requirement. Students plan a community-based project that is of value to the community and consistent with their academic majors. For information, see the CPS website, at https://cps.tulane.edu/academics/public-serviceinternship-program.

A second popular option for completing the graduation requirement is participation in CBR. Students can conduct projects collaboratively with a faculty member as an independent study or an honors thesis. To encourage options for students to engage in such research, the CPS has supported faculty members in developing CBR projects. At the time this research was conducted, the CPS website (CPS, Tulane University, n.d.) described funding opportunities:

The Center for Public Service defines community-based research (CBR) as collaborative, change-oriented research that engages faculty members, students, and community members in projects that address community needs. CBR develops, not only the civic capacity of students, but it also empowers community members, creates self-sustaining communities and has the possibility of effecting social change. Catalyzed by Tulane University's commitment to local and regional neighbors, the Community-Based Research grant program provides Tulane faculty members with the financial resources required to conduct research that advances Tulane University's research and civic agendas in the context of New Orleans ...

The CPS has awarded CBR grants to faculty each year since 2007. Grant amounts range from $\$ 2,500$ to $\$ 4,000$; four to six awards are made each year. Preference is given to faculty proposals that include student involvement in each stage of the research. To encourage faculty efforts, CPS facilitates workshops, seminars, and courses on CBR (https:// cps.tulane.edu/funding/faculty-funding).

Community-engaged research projects that were supported by Tulane University's CPS in recent years represent a wide range of academic disciplines, with a variety of roles for student researchers. Although articles have been written about methods for creating effective CBR experiences for students (Marullo et al., 2003; Polanyi \& Cockburn, 2003; Puma, Bennett, Cutforth, Tombari, \& Stein, 2009), few studies have reported outcomes for students' participation in CBR (Lichtenstein, Thorme, Cutforth, \& Tombari, 2011).

Other options for completing the second public service graduation requirement include courses involving international service, leadership experiences related to service-learning and community engagement, or capstone experiences in the major area of study. See https://cps.tulane.edu/about/ graduation-requirement.

The present study focuses on survey data obtained from Tulane University graduates two years after they completed their undergraduate degrees. Many of the studies cited above evaluated the effects of college service-learning experiences by asking graduates about civic behaviors, which they reported on some years after college completion (Denson et al., 2005; Fenzel \& Peyrot, 2005; Hahn, 2015a, 2015b; Wilder et al., 2013). We used a similar approach, correlating college service-learning experiences and later reports of service activities. Another approach to understanding the effects of college service is to ask alumni about their impressions of the possible later impacts of such experiences. Several researchers have adopted this approach (Caulfield \& Woods, 2013; Korfmacher, 1999; Newman \& Hernandez, 2011). In this way, the researcher can investigate effects that might be difficult to observe directly (e.g., civic attitudes and knowledge or career influences). We included items asking alumni about their perceptions of the impacts of college service to see if alumni perceptions would correspond to the findings we obtained 
regarding the correlations of college experiences and later service and attitudes. We chose to use a survey rather than another method of data collection, because it allowed us to obtain responses from a larger number of individuals than we could practically have done using interviews or focus groups. Offering the survey online made it possible to obtain data from individuals living in a wide range of cities and states. We have found surveys of this kind to be useful in our previous research, yielding data that are reliable, can be subjected to statistical analysis, and that have shown evidence for content and construct validity (e.g., Moely \& Ilustre, 2011, 2013, 2016a, 2016b).

The research questions were as follows:

Research Question 1: How do alumni view the public service requirement they had completed to graduate? What kinds of service did they perform to meet the requirement?

Research Question 2: What kinds of public service are alumni doing two years after completing college?

Research Question 3: Are academic and cocurricular public service activities during college related to alumni service and attitudes?

Research Question 4: What are the relative influences on alumni service and civic attitudes of participation in service-learning, public service internships, CBR, and other public service courses?

Research Question 5: Do alumni see their service-learning or public service experiences during college as influencing their lives and activities after college?

\section{Method}

\section{Research Participants}

The participants in the study were 359 alumni (62\% female) of Tulane University, who had completed their undergraduate studies in 2010, 2011, or 2012, and who were surveyed two years after graduation. The sample represents $10.4 \%$ of the graduating classes in those three years. Nearly half (48\%) of the research participants were enrolled in graduate or professional degree programs at the time of the survey, while $42 \%$ were pursuing a career and not seeking advanced education, $6 \%$ were engaged in full-time work that they did not plan to pursue as a career, and the remainder were involved in other activities. The participants' career goals included a wide range of professional positions and activities within the fields of medicine, public health, or global health $(28 \%$ of those responding), business ( $22 \%$ of the respondents were seeking positions with established firms, starting new companies, working for nonprofits, etc.), law $(19 \%)$, education (9\%), arts and architecture (7\%), and science and technology (4\%). Although the open-ended question about career goals did not focus on civic participation, $10 \%$ of the respondents mentioned career goals that involved working for the benefit of society within traditional fields such as medicine or law, while another $7 \%$ aimed to do so through careers in government, urban planning, international development, human rights organizations, and so on.

Additional information was available for 81 of the alumni who had participated in our longitudinal study (Moely and Ilustre, 2011, 2016a): 72\% were female, $83 \%$ were White, $88 \%$ were not from Louisiana (the state in which Tulane University is located), and about half had parents with advanced degrees (fathers: 50\%, mothers: 49\%). The mean high school GPA was $3.76(S D=0.35)$. Comparing those who responded to the invitation to complete the alumni survey with those from the longitudinal study who did not, we found no differences in gender, race (White vs. other), fathers' education, mothers' education, religiosity, or in interests expressed at college entry regarding civic involvement, academic pursuits, or social skill development. The only difference found was that those who responded were less likely to be from Louisiana than those who did not respond. (Of the respondents, 13\% were from outside Louisiana, while $25 \%$ were from New Orleans or other parts of Louisiana.)

\section{Data Collection Procedure}

The participants were invited to complete a survey two years after graduation, with data collected from the appropriate groups in 2012, 2013, and 2014. Contact information was obtained from the Tulane University Alumni Office and potential participants were sent an email informing them that the survey was available for their consideration on a data collection website. Several reminder emails were sent to those who had not responded after several weeks. Those participating were eligible for a drawing through which an iPad was awarded each year. The procedures used in this study were approved each year by the Tulane University institutional review board (IRB).

\section{Measures}

The alumni were asked about their current educational or work activities and their professional and 
career goals. They also indicated their involvement in academically based and volunteer service during college, reporting the numbers of service-learning courses taken, public service internships completed, CBR courses, and other public service experiences that had earned academic course credit (independent studies, international service-learning, capstone courses, etc.). They indicated the extent of their involvement in volunteer service experiences organized by Tulane University groups (such as the CPS, a campus-wide service organization called CACTUS, or Greek organizations), estimating the number of hours they had spent volunteering yearly while in college using a six-point scale ranging from "rarely volunteered" to "more than 60 hours per year."

We asked the participants about their views of the public service graduation requirement, asking them to respond to this question:

Your class was one of the first to complete the public service graduation requirement. Looking back, what is your opinion of this requirement? Did you think it was (1) a bad idea, (2) OK, (3) a good idea, or (4) do you not have an opinion about this?

The responses were coded by the percentage of participants selecting each of the four categories. In previous research, we found that $57 \%$ to $70 \%$ of Tulane students viewed the requirement as a "good idea" and only $4 \%$ to $6 \%$ saw it as a "bad idea." This positive attitude toward the requirement was consistent from college entry to just before graduation (Moely \& Ilustre, 2016a).

The participants indicated the kinds of public service activities in which they had participated in the two years since graduation, rating items describing different kinds of service by indicating how often they engaged in each activity. As shown in Table 1, their responses mentioned volunteer and programmatic work in the community, donations, and political or civic activities. For analysis, the number of activities (out of a total of 12) for which an individual indicated participation once a month or more often was summed to yield a total score for the amount of current service. (The scores could range from 0 to 12.) The items showed a moderate level of internal consistency (coefficient $\alpha=.71$ ). The mean score reflected a rather low level of involvement in service activities $(M=1.63, S D=$ $1.96, N=317)$. Another way of treating these data would be simply to sum the 1 to 5 scores obtained for each item. In response to reviewers' concerns, we treated the data as ordinal, to prevent violating statistical assumptions. However, the findings were similar for the two approaches.

The alumni were asked how much their servicelearning and public service experiences at Tulane University had influenced them in various aspects of their lives. As shown in Table 2, the items were concerned with outcomes in the areas of civic interest and participation, career development, and the participants' philanthropic donations. For analysis, the number of items (out of a total of 11) for which

Table 1

\section{Alumni Public Service since Graduation}

Please indicate the kinds of public service/community engagement in which you have participated since graduation.

Use the following scale to respond:

$0=$ no involvement

$1=$ took part several times a year

$3=$ engaged in this activity approximately once a month

$4=$ engaged in this activity at least twice a month

$5=$ more than twice a month

Item $\%$ Monthly or More Often

Volunteer at a nonprofit organization

$34 \%$

Volunteer at a school, hospital, or other public agency

$21 \%$

Other volunteer work

Donate money to a local agency or organization (food bank, homeless shelter, etc.)

Donate money to a national nonprofit or philanthropic organization (UNICEF, Red

Cross, etc.)

Create a program to benefit the community

Volunteer at a religious organization (church, temple, mosque)

Serve on the Board of a community agency or philanthropic organization

Participate in a neighborhood/civic association

Belong to a political organization

Work for a political campaign

Run for public office
$20 \%$

$18 \%$

$15 \%$

$12 \%$

$11 \%$

$11 \%$

$9 \%$

$8 \%$

$3 \%$

$0 \%$ 
Table 2

Later Influence of College Public Service as Perceived by Alumni

To what extent did your service-learning/public service experiences at Tulane University influence you with regard to each of the following? Please respond using a scale where:

$1=$ not at all influential

$2=$ slightly influential

$3=$ moderately influential

$4=$ very influential

Item $\%$ Moderately or Very Influential

These experiences have given me strong ties to the city of New Orleans.

These experiences have increased my interest in community issues.

$61 \%$

$43 \%$

$42 \%$

These experiences helped me differentiate myself from other applicants when applying for jobs or to graduate/professional schools.

These experiences have influenced me to engage in volunteer work in my community.

These experiences have influenced my career choices.

These experiences have given me strong ties to the university.

These experiences have influenced my decisions regarding further education.

These experiences have helped me in my job search.

These experiences have made it more likely for me to contribute to Tulane University.

These experiences have made it more likely for me to contribute to philanthropic organizations.

These experiences have increased my interest in politics.
$39 \%$

$37 \%$

$35 \%$

$34 \%$

$33 \%$

$30 \%$

$26 \%$

$18 \%$ an individual indicated a moderate or strong influence was added up to yield a total score for influence of service $(M=3.97, S D=3.59, N=317)$. The items showed high internal consistency $(\alpha=.89, N$ $=317$ ), reflecting a unified view of the impact of community-based college experiences. Again, our findings were the same for this measure as for a measure obtained by summing the 1- to 4-point ratings individuals gave for each of the items.

A shortened version of the scales used in the longitudinal study to measure students' civic attitudes, knowledge, and skills was created (see Table 3). A principal components factor analysis of the items, with varimax rotation, yielded a three-factor solution that accounted for $60.6 \%$ of the variance in scores and validated the conceptualization of the scale components as civic attitudes, knowledge, and skills (Table 3 ).

A repeated-measures analysis of variance of the civic attitudes, knowledge, and skills scores showed a significant main effect of measurement domain, $\mathrm{F}(2,308)=27.61, \mathrm{p}<.001$, partial $\eta 2=$ .147 , with higher ratings given for the civic skills measure than for civic attitudes or civic knowledge, as shown in Table 3. The similarity of factors and differences in mean values to those shown for the longer scales used in our previous research (Moely \& Ilustre, 2011, 2013, 2016a) offer evidence for the construct validity of this brief three-part measure.

Finally, the participants were invited to answer open-ended questions concerning their career goals and public service experiences during college that were important to them. Their answers were grouped conceptually, and the summaries were used to elaborate the findings of the quantitative measures.

\section{Results}

\section{Service Experiences during College}

The first research question concerned alumni views of the public service graduation requirement and the service activities undertaken to complete the requirement. Views were generally positive regarding the requirement, with $63 \%$ viewing it as a "good idea" and 25\% judging it to be "OK."Only $7 \%$ rated it to be a "bad idea." These numbers are very similar to those shown by the participants in the longitudinal study at college entry, after two years, and after four years of college (Moely \& Ilustre, 2016a).

The most common way of completing the graduation requirement was through service-learning course work, with the majority (69\%) of the participants having completed two or more such courses. Instead of completing a second service-learning course, or in addition to it, students could choose more advanced public service course work. One or more public service internships were reported by $43 \%$ of the participants, while $40 \%$ engaged in CBR, and $40 \%$ took 
Table 3

Measuring Alumni Civic Attitudes, Knowledge, and Skills

Civic Attitudes: $M=3.95(S D=.71)$, internal consistency $\alpha=.72, N=310$

I have a strong interest in working with people from diverse backgrounds.

We need to institute reforms within the current system to change our communities.

$4.17(0.82)$

It is important for me to be involved in community service.

$3.88(0.97)$

I think it is important for a person to think about his or her racial identity.

Civic Knowledge: $M=3.85(S D=.78), \alpha=.80, N=310$

I am well-informed about current news events.

$4.12(0.83)$

I am well-informed about the issues facing this nation.

I am aware of significant events happening in my community.

$3.96(0.89)$

I read the local newspaper (or online version) every day.

Civic Skills: $M=4.12(S D=0.59), \alpha=.71, N=310$

I can successfully resolve conflicts with others.

I find it easy to relate to people from a race or culture different from my own.

$4.13(0.81)$

I am a good leader.

I am able to deal effectively with biases or stereotyping directed at me by a person from a different

culture or race.

Note. Participants indicated their views using a scale in which $1=$ strongly disagree, $2=$ disagree, $3=$ neither agree nor disagree, $4=$ agree, and 5 = strongly agree.

part in one or more other public service academic experiences. Many of the students $(60 \%)$ completed more than the two required courses. The participants evaluated their academically based public service experiences as having been positive $(64 \%)$, while only $7 \%$ rated them as negative. The participants estimated the number of hours they had spent yearly during college in non-academic volunteer service organized by university groups. The median response was 11 to 20 hours per year, indicating a fairly low level of volunteer participation.

In response to an open-ended question about "a [college] public service experience that was really important to you," the participants described varied activities: Activities involving children and families were mentioned most frequently (by $20 \%$ of the sample). The participants also mentioned efforts to repair or replace homes lost to Katrina (8\%) and service in the medical field (7\%). Other activities, mentioned by $2 \%$ to $5 \%$, included service in the areas of community organizing, law and government, history and culture, environment, food security or community gardens, and special populations (handicapped, aged, homeless persons, or addicts). Most of the service described by the participants appears to have been carried out locally, although $4 \%$ mentioned international service experiences. Although they were not specifically asked to explain why these experiences were important, some of the participants elaborated, describing opportunities to learn about other people and cultures and to increase their awareness of injustices and neglect in society ( $7 \%$ of respondents); indicating that the service activities had fit with their career plans, giving them experience and knowledge that they were able to use in graduate school and/or careers $(6 \%)$; or focusing on personal rewards they had gained from seeing improvements in people and places, which they attributed to their efforts and those of their peers (building a house, teaching a child to read, fundraising for a cause, or other experiences, mentioned by $5 \%$ of the participants).

\section{Alumni Public Service}

The second research question concerned the public service in which alumni were engaged two years after college graduation. We found that $91 \%$ of participants indicated that they had been involved in some service during those two years, but they did not report frequent or regular service activities. As shown in Table 1, their participation was, on average, limited to activities occurring several times per year. The most frequent way that participants engaged in service was by volunteering at established organizations or agencies. They also donated money occasionally; their involvement in political activities was limited.

\section{Influence of College Service on Later Service and Attitudes}

Next, we addressed the third research question, concerning possible relationships between the 
amounts of service alumni had completed during college and their later involvement in public service and civic attitudes. Several investigators have shown that service-learning makes unique contributions to the prediction of alumni attitudes and behavior, beyond the influence of non-academic service participation (Denson et al., 2005; Fenzel \& Peyrot, 2005). Building on this research, we used two-step regression analyses to look, first, at the influence of non-academic, co-curricular service on alumni outcomes and, second, to evaluate possible additional contributions of service-learning or public service coursework on outcomes. As shown in Tables 4 and 5, alumni who reported more time spent on co-curricular service were currently performing more public service (Table 4-a), had more positive views of the impacts of their college service (Table 4-b), and scored higher in civic attitudes, civic knowledge, and civic skills (Table 5). The analyses controlled for gender, showing a significant gender difference only for civic attitudes, with women obtaining higher scores than men, as also seen in previous research (Moely \& Ilustre, 2011). Does academic coursework contribute anything more to the outcomes? In step 2 of the regression analyses, the total number of service-learning or public service courses that alumni reported having completed was entered as a predictor. As shown in each analysis (Tables 4 and 5), the number of public service courses taken contributed significantly to alumni service and attitudes, beyond the effects shown for non-academic service.

Given these positive findings, we next looked at the importance of the several ways in which students could meet the public service graduation requirement (Research Question 4). Table 6 shows the correlations between different kinds of public service coursework and alumni service and attitudes. As indicated, the relationships between college coursework and later outcomes are the strongest for the more advanced course options: public service internships, CBR projects, and additional public service courses, with the most consistent significant relations seen for participation in CBR. Service-learning coursework, on the contrary, was not significantly related to most of the service or attitude measures. This finding may be an artifact of the fact that all students completed at least one such course for the first part of the public service graduation requirement, thus limiting possible variability in scores.

\section{Alumni Views of Service Impacts}

The fifth research question concerned the participants' views of the extent to which public service experiences during college had influenced them in different aspects of life. Consistent with alumni reports of current service, the alumni saw college service as having an impact on their interest in community issues and volunteer work, as shown in Table 2. In addition, the alumni saw their service as having positive impacts on their ties to the city and on aspects of their career development. The alumni saw their service as less influential on their interest in politics or the likelihood that they would donate to worthy organizations. Alumni views of the impact of their college experiences were related to both curricular and non-curricular service (Table 4b); the correlations (Table 6) show that their views were related significantly to the numbers of servicelearning courses, public service internships, CBR

Table 4

Predicting Alumni Service and Views of Service from Co-curricular and Academic Service during College

\begin{tabular}{|c|c|c|c|}
\hline & $b$ & $S E b$ & $\beta$ \\
\hline \multicolumn{4}{|l|}{$\begin{array}{l}\text { (a) Current Alumni Public Service } \\
\text { Step 1: Adjusted } R^{2}=.046, F(2,305)=8.38, p<.001\end{array}$} \\
\hline Gender & -.081 & .227 & -.020 \\
\hline Amount of co-curricular service & .248 & .061 & $.229 * * *$ \\
\hline \multicolumn{4}{|l|}{ Step 2: $R^{2}$ change $=.082, F(1,304)=28.70, p<.001$} \\
\hline Total number of service-learning/public service courses & .317 & .059 & $.297 * * *$ \\
\hline
\end{tabular}

$* * * p<.001$ for individual variables contributing to prediction

(b) Views of the Later Influence of College Public Service

Step 1: Adjusted $R^{2}=.160, F(2,305)=30.30, p<.001$

Gender

Amount of co-curricular service

$.207 \quad .388$

$.799 \quad .104$

.707

.098

.028

$.404 * * *$

Step 2: $R^{2}$ change $=.122, F(1,304)=52.17, p<.001$

Total number of service-learning/public service courses

$* * * p<.001$ 
Table 5

Predicting Alumni Civic Attitudes, Knowledge, and Skills from Co-curricular and Academic Service during College

$b \quad S E b \quad \beta$

(a) Civic Attitudes

Step 1: Adjusted $R^{2}=.056, F(2,298)=9.87, p<.001$

Gender

Amount of co-curricular service

.082

.022

$.215 * * *$

Total number of service-learning/public service courses

$* * p<.01 ; * * * p<.001$

(b) Civic Knowledge

Step 1: Adjusted $R^{2}=.023, F(2,298)=4.49, p<.05$

Gender

Amount of co-curricular service

$\begin{array}{rrr}-.160 & .094 & -.098 \\ .063 & .025 & .146\end{array}$

Step 2: $R^{2}$ change $=.022, F(1,297)=6.80, p<.01$

Total number of service-learning/public service courses

.065

.025

$.153 * *$

$* p<.05 ; * * p<.01$

(c) Civic Skills

Step 1: Adjusted $R^{2}=.034, F(2,298)=6.33, p<.01$ Gender

Amount of co-curricular service

Step 2: $R^{2}$ change $=.016, F(1,297)=5.07, p<.05$

Total number of service-learning/public service courses

.042

.019

$.132 *$

$* p<.05 ; * * * p<.001$

Table 6

Relations between Kinds of Academically Based Service during College and Alumni Outcomes

\begin{tabular}{lccccc}
\hline & \multicolumn{5}{c}{ Alumni Outcomes } \\
\cline { 2 - 6 } College Service Experiences & $\begin{array}{c}\text { Current } \\
\text { Alumni } \\
\text { Number of Service-learning Courses }\end{array}$ & $\begin{array}{c}\text { Views of } \\
\text { SL/PS } \\
\text { Influence }\end{array}$ & $\begin{array}{c}\text { Civic Attitudes } \\
\text { Service }\end{array}$ & $\begin{array}{c}\text { Civic } \\
\text { Knowledge }\end{array}$ & $\begin{array}{c}\text { Civic } \\
\text { Skills }\end{array}$ \\
\hline Number of Public Service Internships & .02 & $.16^{*}$ & .08 & .07 & .01 \\
Number of Community-Based Research Projects & $.23^{* * *}$ & $.31^{* * *}$ & $.19 * *$ & .06 & .10 \\
Number of Additional Public Service Courses & $.25^{* * * *}$ & $.34^{* * *}$ & $.20^{* *}$ & $.15^{* *}$ & $.12^{*}$ \\
\hline
\end{tabular}

$* p<.05 ; * * p<.01 ; * * * p<.001$.

projects, and other public service academic courses they had taken (Table 6). The more alumni had been involved in these academic experiences, the greater the impact they saw of their college service on their later lives.

\section{Discussion}

As in our previous research, the alumni surveyed here showed positive views of the public service graduation requirement that Tulane University implemented after Hurricane Katrina. It is encouraging that these response patterns have been maintained from the beginning of our longitudinal study in 2006 through the final round of data collection in 2014, with participants strongly endorsing the requirement and only about 5\% of them viewing the requirement negatively. As we have noted in previous work, social-psychological theory (Stukas, Snyder, \& Clary, 1999) would emphasize two factors responsible for these positive attitudes: First, that the individuals who chose to attend this university apparently found the public service requirement to be consistent with their own values and preferences, and, second, that the implementation of the requirement at this university was done in such a way that individuals could find a variety of ways to meet it.

In addition to having positive views of the requirement, the alumni gained from their service: 
Academically based service during college was related to alumni involvement in service, their views of the impact of the service experience, and their civic attitudes, and the influence went beyond that seen with co-curricular service. Similarly, other researchers have shown that service-learning has an impact on outcomes that add to the effects of volunteer community service (Astin, Vogelgesang, Ikeda, \& Yee, 2000; Fenzel \& Peyrot, 2005). Our sample is somewhat different from those used in previous studies, as all of our participants were required to complete at least some service-learning. In this sample, it was participation in higher-level academically based public service courses that was related to alumni outcomes. Why might these advanced experiences be important? Public service internships give students the opportunity to design their own service experiences, while still supporting them with a weekly seminar that deals with issues that arise from community work. Communitybased research usually involves close work with community representatives as research is designed, implemented, and interpreted (Lichtenstein et al., 2011), as well as close work with faculty supervisors who support the students' efforts. Honors theses and independent studies courses offer students opportunities for creative efforts not always available through regular course offerings. Generally, then, the public service courses that have an impact on later community or civic involvement give students opportunities for creative efforts that build on previous community-based experiences, but with faculty supervision and the support of CPS staff as needed. Such courses are likely to produce some of the positive impacts noted by Winston (2015), including increases in knowledge about and skills for community engagement, feelings of self-efficacy about one's capacity to accomplish positive change, and building an identity of value-based service involvement. These findings have clear implications for other colleges and universities aiming to further civic competence and involvement: It is important in program development to create structured opportunities for students to be involved in communitybased learning beyond the single service-learning course. Such opportunities should support students' independent efforts while still providing supportive agents as necessary. Ideally, these advanced experiences can build on things learned during an initial exposure to the community through co-curricular service or a lower-level service-learning course.

The importance of co-curricular service is also highlighted by our findings. Alumni who had participated in co-curricular service in college reported higher levels of public service as alumni, were positive about the impacts of such service, and ranked more highly on measures of civic attitudes, knowledge, and skills. Structured service experiences during college provided opportunities for students to acquire knowledge and learn methods needed for community engagement. The participants' positive ratings of their own civic skills are encouraging with regard to civic involvement: Individuals who are comfortable dealing with people and taking leadership roles are more likely to put themselves into situations in which they can gain knowledge about community and political issues and gain experiences that affect their civic attitudes.

Participation in CBR is also important for later service behaviors and attitudes (Table 6). Lichtenstein et al. (2011), in a survey of CBR outcomes, found that students who engaged in CBR reported having made gains in several areas similar to those shown in the present study, especially in professional skills and civic engagement. These professional skills included resolving conflicts, running meetings, delegating, listening to others, and working as part of a team. Civic engagement was concerned with understanding those who are different from oneself, clarifying one's values, and assessing one's likelihood of voting. These are comparable in some ways with the behaviors and skills measured in the present study.

Some caution is required when interpreting our findings. First, the correlations shown in Table 6 are not strong, indicating that uncontrolled and unknown factors contribute to alumni behaviors and attitudes. However, there is consistency in the relationships shown between college experiences and several different alumni measures (Tables 4 and 5), providing evidence of the validity of the findings. Second, the relationships shown are correlational in nature. We have interpreted them to indicate the influence of college experiences, but it is also possible that individuals who value community engagement are more likely to enroll in co-curricular service and the more advanced public service options and to continue to engage in service as alumni. Vogelgesang (2009) has shown persistent value differences between college students who choose service-learning and those who do not, so that individual differences might be responsible for the apparent effects of service-learning. While appreciating the impacts of college co-curricular and academic service experiences, we should also acknowledge that students come to college with attitudes and experience histories that influence the choices they make during college (Moely \& Ilustre, 2016b). In our longitudinal study, we found that both attitudes at college entry and experiences with service during college were important in determining the civic attitudes, knowledge, and skills 
students demonstrated as they advanced through college (Moely \& Ilustre, 2013, 2016a).

The relatively low levels of service involvement reported by the alumni in the present study is not unusual for individuals at this point in their lives. Newman and Hernandez (2011) found that although community service was part of the postgraduation experience of a majority of their survey respondents, the average reported time spent on volunteer or community service activities was only 5.5 hours per year. The participants in the present study were only two years beyond the completion of their undergraduate studies. About half of them had begun their careers and almost as many were pursuing graduate or professional degrees. The service they reported, mostly community-based volunteer activity and donations, involved activities that individuals can easily fit into their schedules and that typically do not require a great deal of advance planning or individual decision making. Participants were less likely to report activities such as creating programs or serving on boards, which are potentially more time-consuming and demanding of attention and decision making.

Warchal and Ruiz (2004) surveyed participants who graduated from college between 1961 and 2002 and found that alumni do more community service each year as the time since graduation increases. In the early years post-graduation, individuals may be busy with graduate or professional school or may be under pressure to establish themselves in their careers. Later on, they have more time to devote to actions consistent with their values regarding civic or community engagement. Flanagan and Levine (2010) have pointed out that stable patterns of engagement can take hold once individuals have settled into adult roles, with steady jobs, marriage, and parenting helping to increase their interest in and concern about community affairs. The individuals in the present study may become more involved in their communities as they establish families and build community ties. Even at later points, however, we have found that individuals gravitate toward service experiences that are organized for them and that are not overly demanding of their time. We previously found that parents of adolescents often take part in service activities through their children's schools or family religious organizations, which provide easily accessible ways to contribute to their communities (Moely and Ilustre 2016b).

The alumni surveyed here saw an influence of their public service during college on their career development. This is consistent with the findings of Korfmacher (1999), Fenzel and Peyrot (2005), and Laursen, Thiry, and Liston (2012), who have all reported positive impacts of service-learning experiences on students' career planning. A lack of interest in political participation was consistent across measures in the present study; as several researchers (Laursen et al., 2012; Meens, 2014; Saltmarsh, Hartley, \& Clayton, 2009) have pointed out, service-learning programs have generally avoided political issues, so it is likely that alumni gained little encouragement for political involvement from their service-learning courses. Winston (2015), on the contrary, found that service-learning led to positive political involvement, from voting to active participation in political meetings or protests, showing an effect far beyond the impacts of other college experiences for individuals two to three years after college graduation. There may be intercampus differences in the interest students show for political involvement, something about which more information is needed.

The present study has a number of limitations, ranging from the individual to the institutional. At the individual level, the data used are reports of the participants' current and earlier experiences, which may be subject to the limitations of memory, bias, or inaccurate estimates. A follow-up to the present study might be an interview study that could go into more depth about alumni's voluntary and required service experiences and the perceived benefits of such service.

With regard to the research design, we were not able to constitute a control group of alumni from the same population of graduates who did not participate in any public service, as all students were required to complete the graduation requirement. Such a comparison would have yielded more definitive findings. It also would have been helpful to be able to trace change over time with a longitudinal design; some of the research participants had taken part in our research during their college years, but the total number of such participants, given missing data at various points in time, made it impossible to limit the research to only these individuals.

At the institutional level, there are issues of generalizability: How representative are these alumni of others attending this university or of those who have attended other universities? Although the subgroup that had participated in the longitudinal study differed very little from the original sample, we do not know how the other participants compare with peers who did not complete the survey. Furthermore, as these alumni had attended a private research university in the Southern United States, we do not know how typical our findings are of impacts that might be seen at other institutions. Questions about these limitations can be addressed in future research.

Despite the above limitations, the findings of this 
study and our longitudinal study (Moely \& Ilustre, 2013, 2016a) in general show that a requirement of service-learning and other public service academic activities can contribute to college students' civic development immediately and after graduation. Students feel positively about the requirement, complete it successfully, often engage in more service than is required, and, as we have shown here, their college experiences have impacts that carry over to life after college.

\section{References}

Astin, A. W., Sax, L. J., \& Avalos, J. (1999). The longterm effects of volunteerism during the undergraduate years. Review of Higher Education, 21(2), 187-202.

Astin, A. W., Vogelgesang, L. J., Ikeda, E. K., \& Yee, J. A. (2000). How service-learning affects students. Los Angeles: Higher Education Research Institute, UCLA. Retrieved from http://www.wcu.edu/WebFiles/PDFs/ howservicelearningaffectsstudents.pdf

Caulfield, J., \& Woods, T. (2013). Experiential learning: Exploring its long-term impact on socially responsible behavior. Journal of the Scholarship of Teaching and Learning, 13(2), 31-48.

Center for Public Service, Tulane University. (n.d.). Available from http://Tulane.edu/cps/

Denson, N., Vogelgesang, L. J., \& Saenz, V. (2005, April). Can service-learning and a college climate of service lead to increased political engagement after college? Paper presented at the Annual Meeting of the American Educational Research Association, Montreal, CA. Retrieved from http://www.heri.ucla.edu/ PDFs/Atlantic_AERA_Final.pdf

Fenzel, L. M., \& Peyrot, M. (2005). Comparing college community participation and future service behaviors and attitudes. Michigan Journal of Community Service Learning, 12(1), 23-31.

Flanagan, C., \& Levine, P. (2010). Civic engagement and the transition to adulthood. The Future of Children, 20(1), 159-179. Retrieved from https://files.eric. ed.gov/fulltext/EJ883084.pdf.

Hahn, T. W. (2015a, November). Relationship of participation in service-learning courses with alumni civic-mindedness. Presentation at the International Association for Research on Service-Learning and Community Engagement Annual Conference, Boston, MA.

Hahn, T. W. (2015b). The relationship of participation in service-learning courses with alumni civicmindedness and effectiveness working with diversity (Research brief). Indianapolis, IN: Center for Service and Learning. Retrieved from https://scholarworks.iupui.edu/handle/1805/10900

Ilustre, V., Lopez, A. M., \& Moely, B. E. (2012). Conceptualizing, building, and evaluating university practices for community engagement. Journal of Higher Education Outreach and Engagement, 16(4). Retrieved from http://openjournals.libs.uga.edu/index.php/jheoe/article/view/906
Jones, S. R., Segar, T. C., \& Gasiorski, A. L. (2008). "A double-edged sword": College student perceptions of required high school service-learning. Michigan Journal of Community Service Learning, 15(1), 5-17.

Keen, C., \& Hall, K. (2008). Post-graduation service and civic outcomes for high financial need students of a multi-campus, co-curricular service-learning college program. Journal of College and Character, 10(2), 115.

Korfmacher, K. S. (1999). Alumni perspectives on environmental service-learning: Implications for instructors. Michigan Journal of Community Service Learning, 6, 38-52.

Laursen, S. L., Thiry, H., \& Liston, C. S. (2012). The impact of a university-based school science outreach program on graduate student participants' career paths and professional socialization. Journal of Higher Education Outreach and Engagement, 16(2), 187-194. Retrieved from http://openjournals.libs.uga.edu/index. php/jheoe/article/view/1397/846

Lichtenstein, G., Thorme, T., Cutforth, N., \& Tombari, M. L. (2011). Development of a national survey to assess student learning outcomes of community-based research. Journal of Higher Education Outreach and Engagement, 15(2), 7-33.

Marks, H. M., \& Jones, S. R. (2004). Community service in the transition: Shifts and continuities in participation from high school to college. Journal of Higher Education, 75(3), 307-339.

Marullo, S., Cooke, D., Willis, J., Rollins, A., Burke, J., Bonilla, P., \& Waldref, V. (2003). Community-based research assessments: Some principles and practices. Michigan Journal of Community Service Learning, 9(3), 57-68.

Matthews, P. H., Dorfman, J. H., \& Wu, X. (2015). The impacts of undergraduate service-learning on postgraduation employment outcomes. International Journal of Research on Service-Learning and Community Engagement, 3(1). Retrieved from http://journals.sfu. ca/iarslce/index.php/journal/article/view/109/71

Meens, D. E. (2014). Democratic and social justice goals in service-learning evaluation: Contemporary challenges and conceptual resources. Michigan Journal of Community Service Learning, 21(1), 41-54.

Moely, B. E., \& Ilustre, V. (2011). University students' views of a public service graduation requirement. Michigan Journal of Community Service Learning, 17(2), 43-58.

Moely, B. E., \& Ilustre, V. (2013). Stability and change in the development of college students' civic attitudes, knowledge, and skills. Michigan Journal of Community Service Learning, 19(2), 21-35.

Moely, B. E., \& Ilustre, V. (2016a). Outcomes for students completing a university public service graduation requirement: Phase 3 of a longitudinal study. Michigan Journal of Community Service Learning, 22(2), 16-30.

Moely, B. E., \& Ilustre, V. (2016b). Pre-college factors influencing college students' civic attitudes: The importance of familial and community service experiences. International Journal of Research on 
Service-Learning and Community Engagement, 4(1). Retrieved from http://journals.sfu.ca/iarslce/index. php/journal/article/view/222/12

Newman, C. M., \& Hernandez, S. A. (2011). Minding our business: Longitudinal effects of a service-learning experience on alumni. Journal of College Teaching and Learning, 8(8), 39-48. Retrieved from http://www. cluteinstitute.com/ojs/index.php/TLC/article/viewFile/5321/5405

Polanyi, M., \& Cockburn, L. (2003). Opportunities and pitfalls of community-based research: A case study. Michigan Journal of Community Service Learning, 9(3), 16-25.

Puma, J., Bennett, L., Cutforth, N., Tombari, C., \& Stein, P. (2009). A case study of a community-based participatory evaluation research (CBPER) project: Reflections on promising practices and shortcomings. Michigan Journal of Community Service Learning, 15(2), 34-47.

Saltmarsh, J., Hartley, M., \& Clayton, P. H. (2009). Democratic engagement white paper. Boston, MA: New England Resource Center for Higher Education. Retrieved from http://repository.upenn.edu/cgi/viewcontent.cgi? article $=1252 \&$ context $=$ gse_pubs

Stukas, A. A., Snyder, M., \& Clary, E. G. (1999). The effects of "mandatory volunteerism" on intentions to volunteer. Psychological Science, 10(1), 59-64.

Vogelgesang, L. J. (2009). Civic engagement and servicelearning: The challenge and promise of research. In B. E. Moely, S. H. Billig, \& B. A. Holland (Eds.), Creating our identities in service-learning and community engagement (pp. 237-250). Charlotte, NC: Information Age Publishing.

Warchal, J., \& Ruiz, A. (2004). The long-term effects of undergraduate service-learning programs on postgraduate employment choices, community engagement, and leadership. In M. Welch \& S. H. Billig (Eds.), New perspectives in service-learning: Research to advance the field (pp. 87-106). Greenwich, CT: Information Age Publishing.

Wilder, S. O., Berle, D., Knauft, D., \& Brackmann, S. (2013). Long-term effects of service-learning on students' civic engagement after college. Journal of Community Engagement and Scholarship, 6(1), 125-126.

Winston, F. (2015). Reflections upon community engagement: Service-learning and its effect on political participation after college. Journal of Higher Education Outreach and Engagement, 19(1), 79-103. Retrieved from http://openjournals.libs.uga.edu/index.php/jheoe/article/view/1393/842
Authors

BARBARA E. MOELY (moely@tulane.edu) is professor emerita in psychology at Tulane University and has been a research affiliate of Tulane's Center for Public Service. She has published research on service-learning in higher education and has served as the principal investigator for grants supporting service-learning program development. She is a co-editor of two volumes in Information Age Publishing's Advances in Service-Learning Research series: Creating Our Identities in ServiceLearning and Community Engagement (2009) and Research for What? Making Engaged Scholarship Matter (2010). She has served on the Board of the International Association for Research on ServiceLearning and Community Engagement and is a member of the Academy of Community Engagement Scholarship.

VINCENT ILUSTRE (vilustr@tulane.edu) is senior associate vice-president of Advancement at Tulane University. Previously, he was the founding executive director of Tulane University's Center for Public Service, where he provided leadership and vision to ensure that the Center's mission of engaging the university community in public service was achieved. Vincent received his bachelor's degree in sociology and political science from Tulane's Paul Tulane College and his master's degree in business administration in management and marketing from Tulane's Freeman School of Business. He has served on numerous nonprofit boards. 